hogy miként hatott a németalföldi humanista műve a Bibliotheca Vaticana freskóinak kiegészítésére 1610-1611-ben (Giovan Battista Ricci da Novara festményén egy egyiptomi és egy pergamoni könyvtár ábrázolásával).

Hendrickson könyve azonban számomra a jegyzetelés technikáját látva lenyügöző. Valóban, minden, Lipsius által említett könyvtár történetét összefoglalja röviden, a Lipsius által még nem ismert részleteket különválasztva közli velünk. Emellett számos olyan utalást tesz, amelyen keresztül bemutatja az illető könyvtár utótörténetét, hatását valamelyik, a Lipsius korát megelőző időszakban létezett könyvtárra. A jegyzeteket jól áttekinthető alaprajzok, illetve látványtervek egészítik ki az egyes könyvtárakról.

Thomas Hendrickson munkája tehát Lipsius De bibliothecis címü mủvének kritikai kiadása, angol fordítása, egy ókori könyvtártörténet, illetve egy könyvtártan-történet egyben.

MONOK IsTVÁN

\title{
Vestigia II, Magyar források Itáliából, szerk. Domokos György, Kuffart Hajnalka, Szovák Márton, Piliscsaba, Vestigia Kutatócsoport, 2018. 262 p.
}

A 2018 végén jelent meg a 2010-ben indult, a Pázmány Péter Katolikus Egyetemen múködő Vestigia Kutatócsoport második tanulmánykötete, mely a kutatócsoport profiljába illeszkedve, valamint az előző kötet (Vestigia, Mohács előtti magyar források olasz könyvtárakban, szerk. Domokos György, Mátyus Norbert, Armando Nuzzo, Piliscsaba, 2015, [http://vestigia.hu/vestigia.pdf]) hagyományát folytatva az olasz-magyar kapcsolatok történetének újabb részleteibe vezeti be az olvasót. A kötet a 2018 áprilisában Piliscsabán és Esztergomban rendezett kétnapos nemzetközi konferencia előadásainak tanulmánnyá érlelt változatait tartalmazza.

A kötet szerzői között a hazai tudományos élet prominens képviselőin túl nemcsak neves külföldi levéltáros kutatókkal, hanem frissen végzett, illetve végzés előtt álló hallgatókkal is találkozhatunk. Ebből jól látszik, hogy a Kutatócsoport nem csak külföldi kapcsolatainak építését és ápolását, hanem a doktoranduszok és hallgatók kutatásba való bevonását is fontos feladatának tekinti és segíti szakmai előmenetelüket azzal, hogy publikációs felületet biztosít számukra.

A kötet tanulmányait a szerkesztők az első kötethez hasonlóan három részegységre tagolták: Fondok, Források és Perspektívák címmel. Ezen túl a megjelent írásokat tematikájuk szerint ugyancsak három fö csoportra lehet osztani. Az első három olaszországi levéltáros szerzők munkája, melyben felhívják a figyelmet az egyes olasz levéltárakban őrzött, máig feldolgozatlan magyar vonatkozású anyagok sokszínűségére. A második tematikus egység a 2018. évhez kapcsolódóan Mátyás király uralkodása idejére kalauzolja az olvasót (ide sorolható a következő hat tanulmány). A harmadik részbe pedig azon közlemények tartoznak, melyek a török kor - fóként a tizenötéves háború - idején zajló eseményekhez szolgálnak fontos adalékként (öt tanulmány).

Az első tematikus egységben található írások jól szemléltetik, hogy még bőven akad tennivaló az itáliai hungarika kutatás terén. Patrizia Cremonini a Modenai Állami Levéltár igazgatója három fontos forráscsoportra hívja fel a figyelmet: a II. András és Estei Beatrix házasságát igazoló dokumentumra, a II. Estei Alfonz herceg 1566. évi Magyarországi törökellenes hadjáratban való részvételéhez kapcsolódó iratokra, továbbá a 19. században Delle popolazioni che abitano l'Ungheria e la Transilvania címmel írt müre. A második ebbe a csoportba tartozó tanulmány szerzője Federico Gallo a Bibliotheca Ambrosiana rövid történetének bemutatása után az ott őrzött magyar vonatkozású kéziratokra és nyomtatványokra, továbbá azok kutatási lehetőségére és nehézségeire hívja fel a magyarországi kutatók figyelmét. Daniela Ferrari a Mantovai Állami Levéltárban örzött Gonzaga levéltárában található - főként diplomáciai jellegü - iratokat ismerteti vázlatosan, melyek a 14-17. század közötti olasz-magyar kapcsolatokra vonatkozó fontos információkat tartalmaznak. 
A második tematikus egységbe tartozó hat közlemény Hunyadi Mátyás uralkodásának idejére tartalmaz adalékokat. Közös vonásuk, hogy egy kivételével mind függelék formában az elemzett források közlését is tartalmazzák. Az első tanulmány Nyújtódi Székely Miklós 1472. évi követjárását nem csak bemutatja, hanem rövid magyar nyelvü regesztával közli Nyújtódi követutasítását, mely a római Biblioteca Angelica gyüjteményében található (Kalous). Neumann Tibor Pozsony városának számadáskönyveit feldolgozva számos itáliai követségen túl Beatrix királyné itáliai rokonaira vonatkozó adatokat is talált, akik átutazóként fordultak meg a szabad királyi városban. A vonatkozó számadáskönyvi helyek eredeti német nyelvü kiadását, s ezek magyarázatát rövid közleményében végzi el a szerző.

A kötet talán legérdekesebb eredménnyel járó tanulmánya Patrizia Cremonini Andriolo „Fortis"-ról szóló közleménye, melynek jelentősége abban áll, hogy rámutat: a korábban ilyen néven számontartott személy sohasem létezett, a fortis ugyanis ebben az esetben nem több, mint egy üres szó, melynek célja a titkosírással írt levelekben az volt, hogy megtévesszék az olvasókat. Az eset fö érdekessége abban áll, hogy a megtévesztés olyan jól sikerült, hogy évszázadokig félrevezette az azt olvasó kutatókat is...

Kriston Dorottya Anna tanulmánya újabb társadalomtörténeti adalékkal gazdagítja a Mátyáskorról alkotott képünket. Augusto Bencio, Estei Hippolit érsek orvosa részletesen elemzett - $\mathrm{s}$ a függelékben kiadott - fennmaradt levelezésének köszönhetően nyerünk betekintést az itáliai orvos életének problémáiba, mindennapi történéseibe. A következő tanulmány szintén az érseki udvartartás mindennapjaiba enged betekintést. Donato Aretino érseki helynök Modenában megtalált levelei - melyek a Hunyadi Mátyás uralkodását követő évekből származnak - olyan hétköznapi részletekről szolgálnak információkkal, melyeket a magyarországi levéltárakban hiába keresnénk. $\mathrm{Ez}$ - a föként a források közlésére hangsúlyt helyező tanulmány - újabb ékes bizonyítéka az itáliai levéltárak magyarokra vonatkozó rendkívüli adatgazdagságának (Domokos, Schrödl-Libárdi). Az utolsó, tematikáját tekintve Hunyadi Mátyás uralkodása idejéhez köthető mü, Beatrix királyné és unokahúga, Isabella d'Este levelezését mutatja be, rávilágítva a két asszony közötti kölcsönös szeretetteljes viszonyra, továbbá elemezve azok nyelvezetét (Vetrugno).

A bemutatott kötet utolsó tematikus egysége 16-17. századi török háborúk korába nyújt betekintést. A tanulmányok nagyobb része a tizenötéves háború idejére és Esztergom városának történetére vonatkozóan tartalmaznak új adatokat. Ebből a tematikából leginkább az első különül el, mivel egy, az 1543-as magyarországi török hadjáratról szóló követjelentés bemutatását és elemzését tartalmazza - így nem a tizenötéves háború valamely eseményéről számol be (Demjén). A második tanulmány Kanizsa 1601. évi ostromát egy újonnan elökerült itáliai forrás tükrében mutatja be (Huszthy, Kanász, Szovák). Mindkét esetben függelékben olvashatóak az olasz nyelvủ elemzett források is.

A következő két közlemény (Lupoli, Molnár) szervesen kapcsolódik egymáshoz, ugyanis mindkettő Esztergom városának újonnan előkerülő képi ábrázolásait ismerteti (modenai Este-levéltár, spezzanói vár, Modenai Állami Levéltár). A tanulmányok mellett természetesen az elemzett képek is kiadásra kerültek a kötet függelékében. Rosa Lupoli inkább müvészettörténeti-történeti megközelítéssel mutatja be a képek lehetséges készítőit, a képek megrendelőjét, s a képek elkészülési körülményeit. Molnár Ádám a régész szemével vizsgálja a képi forrásokat összevetve azokat a 20. század és a közelmúlt régészeti eredményeivel. E két tanulmánynak köszönhetően a kötet már nem csak a történészek, hanem a müvészettörténészek és régészek érdeklődésére is számot tarthat.

A záró tanulmány (Szovák) Bernardino Zambotti Diario ferrarese címủ munkájának magyar vonatkozású adatait ismerteti. A Ferrara mindennapjait bemutató városi krónika követjárásokra, Aragóniai Beatrixra és rokonaira, valamint a ferrarai egyetemet látogató diákokra egyaránt tartalmaz eddig ismeretlen információkat. 
A kötetben egyaránt olvashatók hosszú, nagyobb forráscsoportot részletesen elemző tanulmányok, valamint egy-egy rövid forrásközlést, s annak kommentárját tartalmazó rövid közlemények is. Mindkét csoport közös, fontos, elengedhetetlen eleme a források közlése. Itt tartom szükségesnek megjegyezni, hogy a későbbiekben talán hasznos lehet majd az olasz nyelvű források fordításának kiadása - akár önálló, kiegészítő kötetben -, hogy az olasz nyelvet nem ismerő, ám a középkori magyar történelem kutatásával foglalkozó kutatók számára is könnyen feldolgozhatóvá váljanak. Erre már csak azért is szükség lenne, mert a kötet eddig ismeretlen, máshol nyomtatásban el nem érhető forrásokat tartalmaz, melyek kiemelkedő fontosságúak a magyar medievisztika számára.

A kötet színvonalasan tárja az olvasó elé a kutatócsoport profiljába illő főbb kutatások jelenlegi állását. Több helyen kerülnek elő a további kutatás lehetséges irányvonalai, melyek mentén a Kutatócsoport tagjai a jövőben mindnen bizonnyal haladnak majd. Külön kiemelendő a nagy számú külföldi szerző tanulmánya, mely ékes bizonyítéka a Vestigia Kutatócsoport élénk külföldi szakmai összeköttetésének. A tudományos kapcsolatok másik kötetbeli példája az olasz szerzők gyakori magyar szakirodalomra való hivatkozása, mely szintén a színvonalas tudományos párbeszéd bizonyítéka. A tanulmányokból ugyanakkor az is látszik, hogy a munka még koránt sem ért véget, az itáliai levéltárak igazi kincsesbányák a magyar történészek számára, melyek anyagainak felderítése és feldolgozása a jövőbeli kutatás feladata lesz.

BADIK-SZABÓ TERÉZIA

Anglo-Saxon Kingdoms, Art, Word, War, ed. by Claire Breay and Joanna Story, London, The British Library, 2018* (Kiállítás a British Library-ben 2018. október 19. és 2019. február 19. között. Kurátor: Claire Breay)

A British Library hosszú éveken át előkészített, pompás nagykiállítása Nagy-Britannia történetének különleges korszakát mutatta be, azt a hozzávetőlegesen hétszáz esztendőt, amelyet angolszász korszaknak nevez a történettudomány (https://www.bl.uk/anglo-saxons). A három angolszász törzs, az anglik, a szászok és a jütök a Kr. u. 5. század folyamán vándoroltak be a brit szigetekre, és alapvetően formálták át a szigetek népességének későrómai-kelta jellegü kultúráját. Az angolszász világ legfontosabb öröksége az óangol nyelv, amely az említett törzsekkel érkezett, és nekik köszönhetően vált uralkodóvá a térségben. A korszakot Hódító Vilmos 1066-os győzelme és trónra lépése zárja, amely gyökeresen új korszakot nyitott a szigetország kultúrájában, természetes módon teret engedve a francia befolyásnak.

A kiállítás 180 eredeti mütárgy - egytől-egyig kimagasló darab és számos újdonság - segítségével próbálta meg rekonstruálni ezt a roppant időszakot folyamatosan fókuszálva az írásbeliségben megfogható kultúra mibenlétére és változásaira. A kiegészítő jelleggel elhelyezett tárgyak - szobrok, ékszerek, pénzek, fegyverek - mellett a föszereplők természetesen a kéziratok voltak. Köztük számos olyan „első” és „legkorábbi” darabbal találkozhatott a látogató, amelyek nem csupán a modern Anglia kulturális gyökerei, hanem az európai kultúra egésze szempontjából is kiemelt jelentőséggel bírnak. Ilyen volt például Szent Benedek regulájának legkorábbi fennmaradt kézirata, amely Merciában vagy Dél-Angliában keletkezett 700 körül (Oxford, Bodleian Library, MS Hatton 48; Kat. 21). De a kiállítás igazi szenzációja volt az angolszász Anglia egyik legnagyobb kincse, a Codex Amiatinus, a legkorábbi teljes latin nyelvü Biblia, amely Firenzéből, a Biblioteca Laurenzianából ezerháromszáz év után most először tért haza angol(szász) földre. Ez utóbbi kódex látványában is impozáns: rendkívül vastag, több mint ezer levélből álló kötetről van szó, amelyet különlegesen kialakított, mély tárlóban mutattak be. A Bibliáról csupán a 19. század végén derült ki

* Az ismertető az MTA-OSZK Res Libraria Hungariae Kutatócsoport Fragmenta Codicum Mühelyének, valamint a K 120495 számú NKFIH-program támogatásával készült. 